\title{
Inclusions and exclusions
}

\section{Lourdes Torres ${ }^{1}$}

Published online: 23 November 2020

(c) Springer Nature Limited 2020

It may feel like we are living through unprecedented times, but the unfolding of the COVID-19 pandemic, particularly the toll it has taken on Black, Brown, and Indigenous lives, and the national uprisings around police violence and anti-Blackness, are evidence, once again, of foundational and enduring structural inequities in the United States. Historians remind us that the US has always been marked by profound and persistent inclusions and exclusions at the expense of people of color across historical periods and geographical and institutional spaces. Understanding the origins, manifestations, and consequences of these inclusions and exclusions is a vital and ongoing project.

From multiple perspectives and a range of disciplines, the articles in this issue examine inclusions and exclusions across diverse contexts. The first two articles ask us to consider how we imagine inclusion within a Latinx literary canon, and three additional articles raise issues of immigrant incorporation from the perspective of the transnational movement of immigrant youth, the challenges faced by Indigenous immigrant farmworkers, and the representation of immigrants in the press.

Arguably, canon formation is an ongoing and dynamic process conditioned by multiple and sometimes conflicting factors such as aesthetic evaluation, political pressures, and marketing priorities. Karen Lorraine Cresci posits that, since literary anthologies play a key role in constructing literary canons, examining author and text inclusion in these anthologies is a valuable project. Anthologies help increase overall visibility of featured writers and often influence the authors and literary works taught in schools. Reviewing Latino literature anthologies published between 1997 and 2010, she finds little overlap in terms of authors included. This surprising finding suggests a lack of consensus among Latino literary scholars about the designation of core writers and foundational works of a Latino literary canon. Only eight writers are included in all six anthologies, and there is much variation in the literary works represented. Cresci raises interesting questions about what this situation means in terms of the possibility of consolidating a body of authors and work that speaks broadly to conceptions of Latinidad.

Lourdes Torres

ltorres@depaul.edu

1 DePaul University, Chicago, IL, USA 
Maia Gil'Adí also invites us to consider the Latinx literary canon, from another angle. Although he is not identified in Cresci's survey as one of the core writers included in all the anthologies she surveyed, few would argue with Gil'Adí's contention that Junot Díaz is a central figure in the Latinx canon today. Gil'Adí asks us to consider Díaz's status in the canon in light of allegations of sexual misconduct. Through an analysis of that debate and some of Díaz's nonfictional and fictional works, she argues that Díaz's writing "replicates gendered violence even as it claims to write against it." In light of this assessment, she asks us to revisit how we teach Díaz today and to think in general about our criteria for a works' inclusion in a Latinx canon.

The three articles that follow explore immigrant inclusions and exclusions. Sayil Camacho and Gaspar Rivera-Salgado contribute to studies that center Indigenous immigrant populations. Their project entails working with a state service agency in California to assess the degree to which it was successful in reaching out to agricultural immigrant workers. Operationalizing a practice of "structural humility," which, as Camacho and Rivera-Salgado state, "includes the consideration of socioeconomic structures that perpetuate inequality and reinforce power dynamics," they created guiding principles to challenge preconceived assumptions about the workforce and to establish accountability in their work. The authors provide a useful model for communicating with and serving vulnerable populations such as Indigenous immigrant farmworkers.

Much has been written about the DREAMer movement and the struggles of immigrant youth for inclusion in the United States. Given the high rates of deportations and the fortifying of borders in the US, there is now also a growing body of work on returnees, those young people who, although having spent a large part of their childhood in the US, find themselves back in their birth nations. In a moving case study, Eleanor Petrone shares the story of Ramón, a DREAMer activist who "chose" to return to Mexico when his avenues for pursuing a higher education in the US were obstructed. Ramón's life trajectory was radically transformed as he negotiated immigration politics in the United States and Mexico, and his new life in Mexico. Petrone concludes that, given ongoing globalization and contentious binational politics, educational institutions need to adapt to better serve this fast-growing population of students who experience a transnational life and education across the United States and Mexico.

One space where immigrants seem to be overrepresented is in the media. Unfortunately, as much scholarship attests, too often the media frames immigrants as criminals and invaders. Natalie Delia Deckard, Irene Browne, Cassaundra Rodriguez, Marisela Martinez-Cola and Sofia Gonzalez Leal offer an innovative angle on this scholarship with their fascinating comparison of images of immigrants in the mainstream and Black presses. They explore how the pejorative "controlling image" of Latinx immigrants is amply represented in the Atlanta Journal Constitution, a mainstream press, but is much less common in the Atlanta Daily World, one of that city's newspapers geared toward Black readers. This study is important because it provides perspective on how Latinos are represented in the Black press, a topic rarely considered in media analyses depicting immigrants. Such a focus can be useful to those of us interested in fostering Latinx and Black coalitions and solidarity. 
Finally, we round out the issue with three engaging essays offering poignant reflections on movidas of inclusion and acts of creating revitalizing spaces. Michelle F. Ramos Pellicia provides guidance on how language educators can create an inclusive classroom "where the seeds of change in attitudes can be planted." She describes an innovative project that invites students to document the linguistic landscape of North County San Diego and Riverside County. Through the use of photos and mapping exercises, students come to recognize the wealth of knowledges, multiple languages, and cultural riches that exist in their communities. Adrián Arancibia provides an absorbing history of California's Taco Shop Poets, a group of Chicano/ Latino cultural performers from the 1990a whose creative works were very much fueled by the vexed politics of the times. Finally, through keen observations and vibrant photos, Kee Carillo Warner introduces the idea of "globalizaje" to discuss a range of social, cultural and ecological transformations he encountered on the USMexico borderlands along a coastline of Sonora in the area of San Carlos.

Enjoy!

Publisher's Note Springer Nature remains neutral with regard to jurisdictional claims in published maps and institutional affiliations. 